\title{
From Constitution to Law: Implementing the 2020 Russian Constitutional Changes
}

\author{
Ben Noble | ORCID: 0000-0002-6844-8886 \\ Lecturer, School of Slavonic and East European Studies, \\ University College London, London, UK \\ Associate Fellow, Russia and Eurasia Programme, Chatham House (the Royal \\ Institute of International Affairs), London, UK \\ Senior Research Fellow, Laboratory for Regional Political Studies, Centre \\ for Fundamental Studies, National Research University Higher School of \\ Economics, Moscow, Russia \\ benjamin.noble@ucl.ac.uk

\begin{abstract}
Nikolay Petrov
Professor, School of Politics and Governance, Faculty of Social Sciences, National Research University Higher School of Economics, Moscow, Russia Senior Research Fellow, Russia and Eurasia Programme, Chatham House (the Royal Institute of International Affairs), London, UK
\end{abstract} \\ nikkpetrov@gmail.com
}

\begin{abstract}
Although 4 July 2020 saw the coming into force of constitutional changes in Russia, this was far from the end of the story. Most clearly, these changes to the 1993 constitution required implementation, including through amendments to, and the writing of new pieces of, federal legislation. In part, this process was the mundane work of legal bureaucrats, tweaking and creating many pieces of legislation to reflect the new constitutional text. But the implementation process also reveals much more about the broader constitutional reform project. This article reviews the implementation process, discussing its complexity, the improvisation shown when fleshing out certain new constitutional details, its relationship with other political developments, and the chasm laid bare between Putin's promise of the rebalancing of power in his 15 January 2020 Address to the Federal Assembly versus the reality of reform in practice.
\end{abstract}




\section{Keywords}

Russia - constitutional reform - law-making - State Duma - legislative bills

4 July 2020 saw the coming into force of 206 changes to the 1993 Russian constitution. But this was far from the end of the constitutional reform project. ${ }^{1}$ For one thing, the amendments had basic knock-on effects for the country's legal ecosystem, with a plethora of changes needed simply to update existing legislation and other rules with the new constitutional norms and language. In addition, many of the constitutional changes were simply broad statements that required fleshing out more fully in separate legislation.

On 11 December 2020, Pavel Krasheninnikov—chairman of the State Duma Committee on State Construction and Legislation, and co-chair of the Working Group on Monitoring the Realisation of Constitutional Changes-provided a status update on these legal developments. ${ }^{2}$ On the basis of Krasheninnikov's comments, Rossiiskaia gazeta reported that the 'main part of the work on bringing federal legislation in line with the new norms of the Constitution' was now complete. ${ }^{3}$

This article takes stock of developments in the implementation process up to this point. Specifically, the article surveys the different layers and stages of implementation, discussing what we can learn more broadly about the constitutional reform project from this process, as well as how it relates to other important, concurrent political developments.

1 For a review of the constitutional amendments, as well as of the process of their proposal and adoption, see Elizabeth Teague, "Russia's Constitutional Reforms of 2020", Russian Politics 5 , no. 3 (2020): $301-328$. The use of the word 'reform' in this article reflects its usage in the constitutional change project, rather than a claim by the article's authors that the changes have actually made improvements.

2 This working group was originally named the "Working Group on Preparing Proposals for the Introduction of Amendments to the Constitution", but was renamed following the "nationwide vote" in July 2020 - see "Pavel Krasheninnikov rasskazal podrobnosti ob izmeneniiakh v zakony posle popravok v Konstitutsiiu”, Gosudarstvennaia Duma, 6 July 2020, http://duma .gov.ru/news/48982/.

3 Galina Mislivskaia, "Krasheninnikov: Popravki v Konstitutsiiu zatronuli 136 zakonov", Rossiiskaia gazeta, 11 December 2020, https://rg.ru/2020/12/11/krasheninnikov-popravki-v -konstituciiu-zatronuli-136-zakonov.html. 
The 'colossal' 5 scale of the legal implementation task was quantified by key individuals in the constitutional reform project. Pavel Krasheninnikov noted that around 100 federal laws-including federal constitutional laws-would require amending. ${ }^{6}$ Krasheninnikov later revised this figure up to $150-$ and 'probably $[. .$.$] many more.' 7$ Beyond federal legislation, Andrei Isaev-First Deputy Head of United Russia's State Duma faction-noted in July 2020 that around 650 regional laws and charters would also have to be amended to reflect the constitutional changes. ${ }^{8}$ And, according to Taliia Khabrieva-Working Group co-chair, alongside Senator Andrei Klishas and Krasheninnikovaround 150 Government resolutions (postanovleniia) would need amending. ${ }^{9}$

Up to 11 December 2020, Pavel Krasheninnikov stated that, during the State Duma's autumn session, 25 individual pieces of draft legislation (bills) implementing ${ }^{10}$ constitutional changes had been introduced into the Federal Assembly's lower chamber-19 by President Putin and six formally sponsored by two co-chairs of the Working Group, Klishas and Krasheninnikov. ${ }^{11}$ However,

4 "Chem dal'shev les, tem bol'she drov". Krasheninnikov mentioned this phrase during a meeting of the Working Group on Monitoring the Realisation of Constitutional Changessee "Krasheninnikov: bolee 150 zakonov nuzhdaiutsia v popravkakh posle obnovleniia Konstitutsii", Duma TV, https://dumatv.ru/news/krasheninnikov--bolee-15o-zakonov -nuzhdayutsya-v-popravkah-posle-obnovleniya-konstitutsii.

5 "A. Klishas prinial uchastie $\mathrm{v}$ zasedanii Rabochei gruppy po monitoringu realizatsii konstitutsionnykh izmenenii", Sovet Federatsii, 11 December 2020, http://council.gov.ru/ events/news/122181/.

6 Svetlana Bocharova and Elena Mukhametshina, "Prezident nashel novuiu rabotu soavtoram obnovlennoi Konstitutsii", Vedomosti, 6 July 2020, https://www.vedomosti.ru/ politics/articles/2020/07/05/834001-prezident-nashel.

7 "Krasheninnikov: bolee 150 zakonov ...".

8 Andrei Isaev, "Realizatsiia popravokv Konstitutsiiu”, Rossiiskaia gazeta, 7 July 2020, https:// rg.ru/2020/07/o7/isaev-gosduma-planiruet-priniat-okolo-sta-zakonodatelnyh-izmen enij.html.

$9 \quad$ Bocharova and Mukhametshina, "Prezident nashel ...”.

10 That is, updating existing legislation or writing new legislation to reflect (and, in certain cases, expand upon) the new constitutional language.

11 Mislivskaia, "Krasheninnikov: Popravki ...". As noted below, an additional deputy sponsor-Ol'ga Savast'ianova-co-sponsored one of these bills. 25 was a lower figure than originally expected. Krasheninnikov stated in September 2020 that 50 implementation bills would be submitted to the State Duma during the lower chamber's autumn session—see 'Krasheninnikov dopustil vozmozhnost' vneseniia v Dumu $\mathrm{v}$ osenniuiu sessiiu poriadka $5^{\circ}$ zakonoproektov $\mathrm{v}$ ramkakh realizatsii popravok $\mathrm{v}$ Konstitutsiiu", Interfax, 8 September 2020, https://www.interfax-russia.ru/moscow/ 
focusing only on these initiatives would neglect the other ways in which the constitutional changes impacted the legislative environment in Russia in 2020. There are four such categories.

\subsection{References to Constitutional Changes before the 'Nationwide Vote'}

On 14 March 2020, Vladimir Putin signed his constitutional reform packageintroduced by the president into the State Duma as bill no. 885214-7 on 20 January 2020 - into law. ${ }^{12}$ But this did not immediately introduce changes to the 1993 constitution, given the staggered way in which different articles of the bill came into force. ${ }^{13}$ As is well known, the Kremlin insisted that that would only happen if the whole set of changes were approved by Russian citizens in a popular vote. However, the delay between the adoption of the reform law and the vote-compounded by a long hiatus caused by the coronavirus pandemic - created a period of limbo. It is worth briefly reviewing the details of the improvised voting procedure and how it affected the implementation of new constitutional norms.

According to Chapter 9 of the 1993 constitution, only changes to Chapters 1 , 2 , and 9 require ratification through a popular vote-specifically, a vsenarodnoe golosovanie (see Article 135 of the Constitution), colloquially referred to as a constitutional 'referendum'. Given that the 2020 changes related only to Chapters $3-8$ of the 1993 constitution, such a popular vote was not needed to introduce changes. And yet, it was clear that the Kremlin wanted the popular legitimacy that such a popular vote would give the constitutional amendments. ${ }^{14}$ That required improvising a way to incorporate some type of popular vote into the process for adopting the constitutional changes-but also in a way that minimized constraints on the authorities. ${ }^{15}$ The result was the use of an obshcherossiiskoe golosovanie (an 'all-Russian' or 'nationwide' vote) - hitherto not defined by Russian law and, therefore, not bound

news/krasheninnikov-dopustil-vozmozhnost-vneseniya-v-dumu-v-osennyuyu-sessiyu -poryadka-5o-zakonoproektov-v-ramkah-realizacii-popravok-v-konstituciyu.

12 Bill no. 885214-7- "O sovershenstvovanii regulirovaniia otdel'nykh voprosov organizatsii i funktsionirovaniia publichnoi vlasti", Sistema obespecheniia zakonodatel'noi deiatel'nosti (sozD), https://sozd.duma.gov.ru/bill/885214-7.

13 See Teague, "Russia's Constitutional ...", for an explanation of the process.

14 Ben Noble, "Putin's Plebiscite", Presidential Power, 18 February 2020, https://presidential -power.net/?p=1088o.

15 Ben Noble, "Russia's "nationwide vote" on constitutional reforms", Presidential Power, 19 June 2020, https://presidential-power.net/?p=11174. 
by existing legal requirements for other forms of popular vote, such as referendums. ${ }^{16}$

This improvisation caused confusion, however. There was clear uncertainty regarding how the process would work. For example, when asked by а ввС News Russian (Russkaia sluzhba) journalist about the specifics of the procedure, State Duma speaker Viacheslav Volodin gave an evasive answer. ${ }^{17}$ It turned out that the Working Group had not yet reached a final decision on how the vote would be incorporated into the formal process. This was pure (albeit clumsy) procedural improvisation-constitutional politics on the fly.

The delay between Putin's signing of the reform bill and the 'nationwide vote' resulted in further awkward moments. There were a number of moves appearing to anticipate the constitutional changes not yet formally adopted, thereby undermining the Kremlin's narrative that it was up to the Russian people to have the final, decisive say. For example, the explanatory note for bill no. 960545-7-'On introducing changes to the Federal Law "On Education in the Russian Federation" on questions of educating students', introduced by Putin on 21 May 2020-referred to constitutional changes not yet approved in the 'nationwide vote. ${ }^{18}$ In addition, copies of the 1993 Constitution incorporating the 206 amendments were being sold in Moscow well before the popular vote. ${ }^{19}$

\subsection{Legal Changes before 4July 2020}

References and premature publications are one thing, but legal changes implementing not-yet-approved constitutional changes are quite another. At a Working Group meeting on 30 May 2020, Pavel Krasheninnikov reported that

16 This did not stop some commentators referring to the vote as a "referendum" - see, for example, Oliver Carroll, "Putin declared triumphant in referendum allowing him to rule until 2036-five hours before polls close", The Independent, 1 July 2020, https://www .independent.co.uk/news/world/europe/russia-referendum-putin-rule-2036-yes-vote -a9595711.html.

17 “'Obshchenarodnoe golosovanie" po Konstitutsii-do podpisi Putina ili posle?", $B B C$ Russkaia sluzhba, 23 January 2020, https://www.bbc.com/russian/features-51230534.

18 Bill no. 960545-7- "O vnesenii izmenenii v Federal'nyi zakon "Ob obrazovanii v Rossiiskoi Federatsii" po voprosam vospitaniia”, sozD, https://sozd.duma.gov.ru/bill/96o545 -7. "Putin proposes new bill on patriotic education that references an article not yet included in the Russian Constitution", Meduza, 22 May 2020, https://meduza.io/en/ news/2020/05/22/putin-proposes-new-bill-on-patriotic-education-that-references-an -article-not-yet-included-in-the-russian-constitution.

19 Matthew Luxmoore, "Russia's vote on constitutional changes ...", Twitter, 16 June 2020, https://twitter.com/mjluxmoore/status/1272876173241004032. 
the constitutional changes - having been approved by the Federal Assembly in March, but not yet put to a popular vote-had already 'found their reflection' in certain presidential decrees and laws 'aimed at supporting the population and business. ${ }^{20}$ In short, Krasheninnikov argued that 'some of the amendments to [Russia's] basic law have effectively already started working'-and before the 'nationwide vote'. In a sense, these changes reflected the impatience and frustration experienced by the Kremlin, whose timetable for change was derailed by the coronavirus. The political leadership was itching to realize the changes it knew would be adopted.

\subsection{Legal Changes and Proposals after 4July 2020 but Not Initiated by Putin or Working Group Co-chairs}

Once the result of the popular vote meant that the constitutional changes had come into force, lawmakers were in a much clearer position to begin the task of updating legislation. In a 7 July 2020 article for Rossiiskaia gazeta, Andrei Isaev reported that United Russia's deputies had been tasked by party leader, Dmitrii Medvedev, with preparing changes to existing legislation to implement the constitutional changes. This included changes to the Tax Code then under consideration by the State Duma with the goal of 'consolidating the higher status of the working person [chelovek truda].21

\subsection{Initiatives from President Putin and the Working Group}

The signal constitutional reform implementation bills were sponsored by the president, as well as the double act of Senator Andrei Klishas and State Duma deputy Pavel Krasheninnikov. These are the 25 bills noted above. The following section reviews these initiatives.

\section{Key Constitutional Reform Implementation Bills}

Up to 11 December 2020, President Putin had formally sponsored four 'packets' of draft legislation implementing constitutional changes. The first packetintroduced into the State Duma on 22 September 2020-contained eight bills: a new draft federal constitutional law (FKz) 'On Government', which stipulated, among other things, new rules for appointing the prime minister

\footnotetext{
20 "Krasheninnikov: chast' popravok v Konstitutsiiu uzhe rabotaet v vide zakonov", RIA Novosti, 3o May 2020, https://ria.ru/2020053o/157222150o.html.

21 Isaev, "Realizatsiia popravok ...."
} 
and federal ministers, including the State Duma's role in these appointments; changes to the existing F KZ s 'On the Constitutional Court' and 'On the Human Rights Ombudsperson'; ${ }^{22}$ changes to the existing federal laws 'On Security', 'On the FSB', 'On Foreign Intelligence', and 'On the Procuracy'; ${ }^{23}$ and changes to legislation regarding the termination of senior judges' tenures. ${ }^{24}$ The second packet-introduced into the State Duma on 14 October 2020-contained six bills. Five of these proposed changes related to a variety of legal codes and laws-including Part One of the Civil Code and the Criminal Procedure Code - with the common aim of stating the 'priority of the Constitution' in cases of clashes with decisions of international bodies. ${ }^{25}$ The one other bill

22 Bill no. 1024645-7— “O Pravitel'stve Rossiiskoi Federatsii”, sozD, https://sozd.duma.gov .ru/bill/1024645-7. Bill no. 1024643-7—“O vnesenii izmenenii v Federal'nyi konstitutsionnyi zakon “O Konstitutsionnom Sude Rossiiskoi Federatsii", sozD, https://sozd.duma.gov .ru/bill/1024643-7. Bill no. 1024644-7-“O vnesenii izmenenii v stat'i 6 i 11 Federal'nogo konstitutsionnogo zakona "Ob Upolnomochennom po pravam cheloveka v Rossiiskoi Federatsii”', SOZD, https://sozd.duma.gov.ru/bill/1024644-7.

23 Bill no. 1024649-7- "O vnesenii izmenenii v Federal'nyi zakon "O bezopasnosti" ( $v$ chasti privedeniia nekotorykh polozhenii zakonodatel'stva v sootvetstvie s Konstitutsiei Rossiiskoi Federatsii)", sozD, https://sozd.duma.gov.ru/bill/1024649-7. Bill no. 10246477-“O vnesenii izmenenii v stat'i 1 i 16 Federal'nogo zakona "O federal'noi sluzhbe bezopasnosti" i stat'i 12 i 17 Federal'nogo zakona "O vneshnei razvedke" (v chasti privedeniia nekotorykh polozhenii zakonodatel'stva v sootvetstvie s Konstitutsiei Rossiiskoi Federatsii)", sozD, https://sozd.duma.gov.ru/bill/1024647-7. Bill no. 1024646-7-“O vnesenii izmenenii v Federal'nyi zakon "O prokurature Rossiiskoi Federatsii" (v chasti privedeniia nekotorykh polozhenii zakonodatel'stva v sootvetstvie s Konstitutsiei Rossiiskoi Federatsii)", sozD, https://sozd.duma.gov.ru/bill/1024646-7.

24 Bill no. 1024650-7- “O vnesenii izmenenii v otdel'nye zakonodatel'nye akty Rossiiskoi Federatsii (v chasti privedeniia nekotorykh polozhenii zakonodatel'stva v sootvetstvie s Konstitutsiei Rossiiskoi Federatsii)", sozD, https://sozd.duma.gov.ru/bill/102465o-7. Bill no. 1024648-7-“O vnesenii izmenenii v otdel'nye federal'nye konstitutsionnye zakony (v chasti privedeniia nekotorykh polozhenii zakonodatel'stva v sootvetstvie s Konstitutsiei Rossiiskoi Federatsii)", sozD, https://sozd.duma.gov.ru/bill/1024648-7.

25 Bill no. 1036254-7- 'O vnesenii izmenenii v otdel'nye zakonodatel'nye akty Rossiiskoi Federatsii (o prioritete Konstitutsii Rossiiskoi Federatsii)", sozD https://sozd.duma.gov .ru/bill/1036254-7. Bill no. 1036240-7- “O vnesenii izmenenii v otdel'nye zakonodatel'nye akty Rossiiskoi Federatsii v chasti nedopushcheniia primeneniia pravil mezhdunarodnykh dogovorov Rossiiskoi Federatsii v istolkovanii, protivorechashchem Konstitutsii Rossiiskoi Federatsii (o prioritete Konstitutsii Rossiiskoi Federatsii)", sozD, https:// sozd.duma.gov.ru/bill/1036240-7. Bill no. 1036233-7-“O vnesenii izmeneniia v stat'iu 1 Ugolovno-protsessual'nogo kodeksa Rossiiskoi Federatsii (o prioritete Konstitutsii Rossiiskoi Federatsii)", sozD, https://sozd.duma.gov.ru/bill/1036233-7. Bill no. 10362267-“O vnesenii izmeneniia v stat'iu 7 chasti pervoi Grazhdanskogo kodeksa Rossiiskoi Federatsii (o prioritete Konstitutsii Rossiiskoi Federatsii)", sozD, https://sozd.duma.gov. ru/bill/1036226-7. Bill no. 1036249-7-“O vnesenii izmenenii v stat'i 6 i 165 Semeinogo 
in this second packet was the draft federal law 'On the State Council'. ${ }^{26}$ The third packet—introduced into the State Duma on 31 October 2020—consisted of two bills, both relating to the Federation Council, including giving former presidents the right to become senators for life. ${ }^{27}$ Finally, the fourth packetintroduced into the State Duma on 30 November 2020 - consisted of two bills relating to restrictions on officials with dual nationality and permanent residence rights abroad. ${ }^{28}$

Up to 11 December 2020, Andrei Klishas and Pavel Krasheninnikov had cosponsored seven constitutional reform implementation bills: changes to the law on guarantees for former presidents, specifically concerning immunity; ${ }^{29} \mathrm{a}$ new federal law 'On the federal territory "Sirius"; 30 changes to various federal laws introducing changes regarding the regulation of elections and referendums, including limiting future presidents to two terms; ${ }^{31}$ two bills introducing changes to the Criminal Code and the Code of Administrative Offences,

kodeksa Rossiiskoi Federatsii (o prioritete Konstitutsii Rossiiskoi Federatsii)", sozD, https://sozd.duma.gov.ru/bill/1036249-7.

26 Bill no. 1036217-7—“O Gosudarstvennom Sovete Rossiiskoi Federatsii", sozD, https://sozd .duma.gov.ru/bill/1036217-7.

27 Bill no. 1048141-7- “O poriadke formirovaniia Soveta Federatsii Federal'nogo Sobraniia Rossiiskoi Federatsii", SOZD, https://sozd.duma.gov.ru/bill/1048141-7. Bill no. 10481467-“O vnesenii izmenenii v Federal'nyi zakon "O statuse chlena Soveta Federatsii i statuse deputata Gosudarstvennoi Dumy Federal'nogo Sobraniia Rossiiskoi Federatsii” ( $\mathrm{v}$ chasti privedeniia nekotorykh polozhenii zakonodatel'stva v sootvetstvie s Konstitutsiei Rossiiskoi Federatsii)", sozD, https://sozd.duma.gov.ru/bill/1048146-7.

28 Bill no. 1065309-7- "O vnesenii izmenenii v Trudovoi kodeks Rossiiskoi Federatsii ( $v$ chasti ogranichenii dlia otdel'nykh kategorii rabotnikov v sviazi s nalichiem u nikh grazhdanstva inostrannogo gosudarstva libo prava na postoiannoe prozhivanie na territorii inostrannogo gosudarstva)", sozD, https://sozd.duma.gov.ru/bill/1065309-7. Bill no. 1065287-7- “O vnesenii izmenenii v otdel'nye zakonodatel'nye akty Rossiiskoi Federatsii (v chasti ogranichenii dlia zameshcheniia gosudarstvennykh, munitsipal'nykh dolzhnostei, inykh dolzhnostei v sviazi s nalichiem grazhdanstva inostrannogo gosudarstva libo prava na postoiannoe prozhivanie na territorii inostrannogo gosudarstva)", SOZD, https:// sozd.duma.gov.ru/bill/1065287-7. The number of presidential initiatives noted here comes to 18 , not the 19 declared by Krasheninnikov. If the Working Group co-chair has not simply made a mistake of addition, he could also be including bill no. 960545-7.

29 Bill no. 1049598-7-“O vnesenii izmenenia v stat'iu 3 Federal'nogo zakona "O garantiiakh Prezidentu Rossiiskoi Federatsii, prekrativshemu ispolnenie svoikh polnomochii, i chlenami ego sem'i” (v chasti privedeniia v sootvetstvie s Konstitutsiei Rossiiskoi Federatsii)", sozD, https://sozd.duma.gov.ru/bill/1049598-7.

3о Bill no. 1051718-7— “O federal'noi territorii "Sirius"”, sozD, https://sozd.duma.gov.ru/ bill/1051718-7.

$31 \quad$ Bill no. 1057340-7- “O vnesenii izmenenii v otdel'nye zakonodatel'nye akty Rossiiskoi Federatsii ( $v$ chasti privedeniia zakonodatel'stva o vyborakh i referendumakh $\mathrm{v}$ 
respectively, on punishment for violating Russia's territorial integrity; ${ }^{32}$ changes to various federal laws on removing children facing an immediate threat to their life or health from their family; ${ }^{33}$ and on introducing a change to the federal law 'On countering extremist activity', clarifying the concept of 'extremist activity' in light of constitutional reforms. ${ }^{34}$ The first three Klishas-Krasheninnikov initiatives listed here were introduced into the State Duma in November, ${ }^{35}$ but the final four in the list had been introduced in July. ${ }^{36}$ The bill concerning the removal of children was withdrawn from consideration on 18 November, following a hostile response from influential actors, including the head of the Russian Orthodox Church, Patriarch Kirill. ${ }^{37}$ (This bill withdrawal explains the discrepancy between the number of constitutional reform implementation bills submitted by Klishas and Krasheninnikov (i.e., seven) and the number reported by the latter noted above (i.e., six).)

\subsection{Bill Order and Importance}

This first cluster of implementation bills includes those relating to key political institutions (for example, the Government), initiatives personally important to Putin (for example, on immunity for former presidents), and initiatives relating to important questions of state sovereignty (for example, on the priority of the constitution over decisions of international bodies). It is distinctly

sootvetstvie s popravkami k Konstitutsii Rossiiskoi Federatsii)", sozD, https://sozd.duma. gov.ru/bill/1057340-7.

Bill no. 989303-7- “O vnesenii izmenenii v Ugolovnyi kodeks Rossiiskoi Federatsii i stat'i 30 i 31 Ugolovno-protsessual'nogo kodeksa Rossiiskoi Federatsii (v chasti ustanovleniia otvetstvennosti za narushenie territorial'noi tselostnosti Rossiiskoi Federatsii)", sozD, https://sozd.duma.gov.ru/bill/989303-7. Bill no. 989291-7-“O vnesenii izmenenii v Kodeks Rossiiskoi Federatsii ob administrativnykh pravonarusheniiakh ( $\mathrm{v}$ chasti ustanovleniia administrativnoi otvetstvennosti za publichnye prizyvy $\mathrm{k}$ osushchestvleniiu deistvii, napravlennykh na narushenie territorial'noi tselostnosti Rossiiskoi Federatsii)", SOZD, https://sozd.duma.gov.ru/bill/989291-7.

33 Bill no. 986679-7-“O vnesenii izmenenii v otdel'nye zakonodatel'nye akty Rossiiskoi Federatsii (o poriadke otobraniia rebenka pri neposredstvennoi ugroze ego zhizni)", SOZD, https://sozd.duma.gov.ru/bill/986679-7.

34 Bill no. 985175-7 - “O vnesenii izmeneniia v stat'iu 1 Federal'nogo zakona "O protivodeistvii ekstremistskoi deiatel'nosti” (v chasti utochneniia poniatiia ekstremistskoi deiatel'nosti)”, SOZD, https://sozd.duma.gov.ru/bill/985175-7.

35 On 5, 9, and 17 November, respectively.

36 On 15,15 , 10 and 8 July, respectively.

37 Elena Mukhametshina and Konstantin Glikin, "Zakonoproekt ob iz"iatii detei iz sem'i pri ugroze zhizni i zdorov'iu otozvan iz Gosdumy", Vedomosti, 16 November 2020, https:// www.vedomosti.ru/society/articles/2020/11/16/847138-zakonoproekt-detei. 
possible that initiatives relating to issues more visible, and of keener interest, to Russian citizens - such as regarding traditional values - will be introduced closer to the September 2021 State Duma elections. In other words, the order of the implementation process has been patterned by both the importance of initiatives to the Kremlin and the electoral cycle.

\subsection{Bill Sponsorship}

What explains the formal sponsorship of different bills? Rather than reflecting genuine original authorship - that is, that Klishas and Krasheninnikov developed bills independently of the Presidential Administration-formal bill sponsorship in part reflects a concern for optics. Most notably, it is likely that Putin did not formally sponsor the bill concerning immunity for former presidents in order to maintain political distance from the initiative- to make it seem less like a self-interested move. Like with the amendment formally proposed by Valentina Tereshkova during the main constitutional reform bill's second Duma reading on 10 March, which allows Putin to run again for the presidency in 2024 and 2030, the goal was to make these changes appear to be expressions of popular will rather than presidential existential expediency. ${ }^{38}$ The same logic applies to the bill limiting individuals to two presidential terms in their lifetime, which was sponsored by Klishas, Krasheninnikov, and Ol'ga Savast'ianova - chair of the Duma Committee on Control and the Standing Orders. ${ }^{39}$

\subsection{Bill Amendments}

Given the importance of these initiatives, one might imagine that all bills would have sailed through legislative review without amendment. That was certainly the case for some initiatives. The bill on the State Council was not amended during its second reading in the State Duma. ${ }^{40}$ But other key bills had changes introduced during Duma passage. For example, the bill on the Constitutional Court saw important amendments made, including a ban on publishing dissenting opinions written by judges of the Court, as well as public

38 Ben Noble, "It Wasn't About Putin—Until It Was", The Moscow Times, 3 July 2020, https:// www.themoscowtimes.com/2020/o7/o3/it-wasnt-about-putin-until-it-was-a7077o.

39 Bill no. 1057340-7.

40 Kseniia Veretennikova, "Gossovet ne povod dlia diskusii", Kommersant, 24 November 2020, https://www.kommersant.ru/doc/4584675. 
criticisms by justices of Court decisions, and changes to the eligibility criteria for the Court's leadership. ${ }^{41}$

What explains these changes? Was this a sign of parliamentarians influencing law-making independently of the executive? Unlikely. As previous research on Russian law-making has demonstrated, amendments made to bills during Duma review-especially regarding those initiatives formally sponsored by the executive-more likely reflect executive-initiated updating, including as a result of the resolution of intra-executive policy disputes. ${ }^{42}$ There is also the possibility of political theatre-that certain policy elements, although planned from the beginning, were introduced as amendments to make it seem like they were the sincere suggestions of autonomous, influential deputies. ${ }^{43}$

\subsection{Political Parties, Discussion, and Voting}

With a constitutional majority in the State Duma, the votes of United Russia deputies alone were enough to secure the adoption of these implementation bills. However, the Kremlin appeared keen to ensure a united front by securing the support of all political parties in the Duma for these implementation initiatives. This would be a visible demonstration of the narrative that the constitutional changes were 'adopted by the will of the people'-and, therefore, unimpeachably legitimate. ${ }^{44}$ During a meeting with the leaders of political parties' State Duma factions on 6 October 2020, Vladimir Putin stressed the need for consensus:

It is extremely important that on the most important, fundamental questions you speak in solidarity, take a common position, defend the

41 Yulia Khalikova, "Russia's censored judges”, Riddle, 4 December 2020, https://www.ridl.io/ en/russia-s-censored-judges/. For a discussion of changes relating to the Constitutional Court as part of the constitutional reform project, see Ivan Grigoriev, "What changes for the Constitutional Court with the new Russian constitution?", Russian Politics 6, no. 1 (2021): 27-49.

42 Ben Noble, "Authoritarian Amendments: Legislative Institutions as Intraexecutive Constraints in Post-Soviet Russia", Comparative Political Studies 53, no. 9 (2020):1417-1454. https://doi.org/10.1177/oo10414018797941.

43 Ben Noble and Ekaterina Schulmann, "Not Just a Rubber Stamp: Parliament and Lawmaking", in Daniel Treisman ed., The New Autocracy: Information, Politics, and Policy in Putin's Russia. (Washington, DC: Brookings Institution Press, 2018): 49-82.

44 Marfa Vasil'eva, "Putin: popravki “priniaty po vole naroda"', Euronews, 3 July 2020, https:// ru.euronews.com/2020/o7/o3/putin-amendments-are-peoples-wish. 
sovereignty and security of the country, historical truth, the vital interests of people, and do much to strengthen civil society and its key institutions. ${ }^{45}$

The Communist Party (KPRF) had different ideas. On certain bills-such as the bill on forming the Federation Council (104814-7) — the party voted against the initiative in third reading. On other bills-such as the bill on the State Council - the party abstained in third reading. And on yet other billssuch as the bill 'On Government' - the party did not vote in third reading. However, the party did vote in support of some initiatives in third reading, such as for the bill amending various pieces of legislation affirming the priority of the Russian Constitution (1036254-7). At heart, this varied voting stance is consistent with the KPRF's status as a systemic opposition party: sometimes voting in support of the executive's policy agenda, but sometimes not. And the party leadership's appetite for opposition was also no doubt increased by the upcoming September 2021 State Duma elections; pointing to dissent on key executive bills could come in handy when canvassing for votes.

The KPRF's resistance drew the ire of some, however. President Putin's plenipotentiary representative in the State Duma, Garri Minkh, appeared keen to shut down critical debate. In response to questions posed by KPRF deputies regarding the bill on immunity for former presidents in a plenary session on 17 November 2020, Minkh stated that deputies who 'do not like the Constitution' should give up their mandates as deputies, arguing that Duma members are 'obliged to take decisions within the framework of the Constitution', ${ }^{46}$ The presidential representative's intervention suggested he thought that constitutional reform implementation bills should be adopted automatically, without legislative scrutiny.

Minkh's stance is curious for at least two reasons. Firstly, the constitutional reform project was framed by Vladimir Putin on 15 January 2020 as a way to strengthen parliamentary power-and what does parliamentary power involve if not critical scrutiny of proposed policies? And secondly, the particular bill in question did not simply repeat constitutional changes verbatim. ${ }^{47}$ The

45 Ivan Rodin, "Lidery fraktsii poluchili k prezidentu udalennyi dostup", Nezavisimaia gazeta, 6 October 2020, https://www.ng.ru/politics/2020-10-06/3_7982_leaders.html.

46 Maksim Ivanov, "Garri Minkh obvinil deputatov-kommunistov v popytkakh narushat' Konstitutsiiu”, Vedomosti, 18 November 2020, https://www.vedomosti.ru/opinion/ quotes/2020/11/18/847509-garri-minh. 
Klishas-Krasheninnikov bill moved beyond the constitutional amendment and the existing federal law (12-FZ, 2001) fleshing out guarantees for former presidents. ${ }^{48}$ Specifically, the bill proposed to remove a reference in the law to the fact that former presidents enjoyed immunity only in relation to those actions carried out during an individual's tenure of the presidency. This meant that the new reference in the constitution to immunity for former presidents would apply not only to presidential activities, effectively giving an individual immunity for life.

Regardless of Minkh's position, the speed with which most of the constitutional reform implementation bills passed through the law-making process suggests they were not scrutinized to the degree such important legislation would seem to merit. For example, the bill that became the new federal constitutional law 'On Government' (4-F KZ 202O) was introduced into the Duma on 22 September 2020 and was signed into law on 6 November 2020.49 It took, therefore, 45 days for the introduced bill to become law. By contrast, the version of the law 'On Government' that it replaced (2-FKZ 1997) was introduced into the Duma on 24 April 1996 and was signed into law on 17 December 1997 602 days. ${ }^{50}$ To be sure, these bills were passed in radically different political conditions, including regarding executive-legislative relations. But, especially when taking into account the reduced number of State Duma plenary sessions held as a result of the coronavirus, as well as the other pieces of legislation under consideration at the same time-the 2021-23 state budget bill, most notably - the time taken to pass 4-FKZ (2020) was markedly short.

\subsection{Further Changes}

As demonstrated above, the implementation process does not simply boil down to bills from the president and Klishas-Krasheninnikov. This is also clear when noting further knock-on effects and so-far unimplemented constitutional changes. One clear example of the complexity of updating details and rules at the federal level relates to the State Duma's standing orders (reglament). When the lower chamber of the Federal Assembly came to vote on whether to approve new members of Government on 10 November-for the

48 "O garantiiakh Prezidentu Rossiiskoi Federatsii, prekrativshemu ispolnenie svoikh polnomochii, i chlenam ego sem'i", http://pravo.gov.ru/proxy/ips/?docbody=\&nd=1020696 $25 \& \mathrm{rdk}=3$. This law was first promulgated in 2001 and last amended in 2014 before the Klishas-Krasheninnikov initiative became law.

49 Bill no. 1024645-7.

50 Bill no. 96700534-2—“O Pravitel'stve Rossiiskoi Federatsii", sozD, https://sozd.duma.gov .ru/bill/96700534-2. 
first time since the changed constitutional language on the Duma's role in this process - the body's own rules had not yet been amended to stipulate the precise procedure. Deputies, therefore, devised rules on the fly-improvisation, once again. ${ }^{51}$ And yet, not all of this rule updating was out of sync, with formal rules coming after non-rule-bound practice: thus, the presidential decree 'Questions of the State Council of the Russian Federation', which fleshed out details of the revamped body - with details including information on commissions and post holders - was promulgated after the signing into law of the new federal legislation on the State Council. ${ }^{52}$

Beyond the federal level, the constitutional changes also required amendments to regional legislation and charters/constitutions. The complexity of this task, and the scope for legal inconsistencies across regions and between the regions and the center, prompted Pavel Krasheninnikov to stress the need for a 'systematic' approach, including the writing of 'model' changes that regions could use as templates to ensure consistency - a move agreed to at a meeting of the Council of Legislators at the end of December 2020.53

Beyond the cascade of rule changes already noted, some notable constitutional changes had not seen implementation bills submitted by 11 December 2020 - the cut-off point noted at the start of this article. One of the clearest absences is the general draft legislation on federal territories. So far, only a specific law — on the 'Sirius' region — has been passed. The general bill should make clearer how these territories will fit into the existing federal architecture, as well as how they will relate to the 'unified system of public power'.

51 "Gosduma izmenit protseduru utverzhdeniia ministrov i predsedatelia pravitel'stva", Kommersant, 11 December 2020, https://www.kommersant.ru/doc/4613o66.

52 Ukaz Prezidenta Rossiiskoi Federatsii no. 80o-“Voprosy Gosudarstvennogo Soveta Rossiiskoi Federatsii”, Kremlin, 21 December 2020, http://static.kremlin.ru/media/events/ files/ru/odkAbIRVv2fDJzaAQf 4 IIW55voOY 7 KNA.pdf.

53 "Krasheninnikov prizval sub"ekty RF $\mathrm{k}$ sistemnoi rabote po popravkam $\mathrm{v}$ razvitie konstitutsii", TASS, 11 December 2020, https://tass.ru/politika/10230841. Galina Mislivskaia, "Iarovaia: Nado dat' regionam obraztsy dlia izmeneniia zakonov v sootvetstvii s Konstitutsiei", Rossiiskaia gazeta, 18 December 2020, https://rg.ru/2020/12/18/ iarovaia-nado-dat-regionam-obrazcy-dlia-izmeneniia-zakonov-v-sootvetstvii-s -konstituciej.html. Galina Mislivskaia, "Po edinomu obraztsu", Rossiiskaia gazeta, 2o December 2020, https://rg.ru/2020/12/20/regiony-privedut-svoi-ustavy-v-sootvetstvie -s-novymi-normami-konstitucii.html. On the Council of Legislators, see "Main facts about the Council of Legislators of the Russian Federation", State Duma, 24 April 2019, http://duma.gov.ru/en/news/4468o/. 


\section{Constitutional Reforms in Practice-The State Council and the 'Unified System of Public Power'}

This article has focused on the implementation of constitutional changes in terms of follow-up changes to legislation. However, implementation more broadly relates to how these new rules will function in practice. The case of the State Council can be examined to provide some initial insights.

The rebooted Council met for the first time on 23 December 2020, together with the Presidential Council on Strategic Development and National Projects. ${ }^{54}$ The personal composition of the State Council was announced two days earlier, along with the organizational structure of the body in two presidential decrees. ${ }^{55}$ Speculation about the significance of this revamped body involved a focus on personnel choices, especially the choice of Council secretary. ${ }^{56}$ Rather than appoint a political heavyweight, however, the sitting secretary - Igor Levitin, a trusted presidential aide to Vladimir Putin — was re-appointed. This suggests a degree of continuity in the role of the Council, particularly since this institution-created in 2000 and serving a largely peripheral, symbolic role for most of its existence-partially 'woke up' in November 2018, with the first expanded meeting of its praesidium in Yalta. ${ }^{57}$

The composition of the whole State Council, including all regional heads, means that it will likely function as a largely ceremonial body, with parallels drawn between it and the Central Committee of the Communist Party of the Soviet Union. ${ }^{58}$ However, the Council's praesidium holds the potential for more consequential action. Consisting of 18 regional heads who chair Council commissions, as well as nine additional regional heads and Igor Levitin, the

54 "Sovmestnoe zasedanie Gossoveta i Soveta po strategicheskomu razvitiiu i natsproektam", Kremlin, 23 December 2020, http://kremlin.ru/events/president/news/64736. See also Andrei Vinokurov and Elena Rozhkova, "Gosudarevo "Oko"', Kommersant, 22 December 2020, https://www.kommersant.ru/doc/4625816.

55 Ukaz Prezidenta Rossiiskoi Federatsii no. 799- “Ob utverzhdenii sostava Gosudarstvennogo Soveta Rossiiskoi Federatsii", Kremlin, 21 December 2020, http://publication .pravo.gov.ru/Document/View/ooo1202012210oo1?index=o\&rangeSize=1. Ukaz Prezidenta Rossiiskoi Federatsii no. 8oo.

56 Fabian Burkhardt, Ben Noble, and Nikolai Petrov, "Rebooting the State Council Increases Putin's Power", Chatham House, 28 October 2020, https://www.chathamhouse .org/2020/10/rebooting-state-council-increases-putins-power.

57 For a short overview of the State Council's activities since its creation in 2000, see Ben Noble, "What to Make of Russia's State Council?", RUSI, 18 September 2020, https://rusi .org/commentary/what-make-russia-state-council.

$5^{8}$ Mariia Makutina, "Organ soveshchatel'noi vlasti", Kommersant, 11 November 2020, https:// www.kommersant.ru/doc/4566689. 
praesidium should play a more active role in decision-making and governance. ${ }^{59}$ And yet, the revamped State Council looks set to remain very much a creature of the president and of the Presidential Administration. This is particularly clear from the appointment of Anton Vaino and Sergei Kirienko-Chief of Staff and First Deputy Chief of Staff of the Presidential Administration, respectively - as chairs of key commissions within the Council: for Ensuring the Coordinated Functioning and Interaction of Organs of Public Power; and for the Coordination and Assessment of the Effectiveness of the Activities of Organs of Executive Power of the Regions. ${ }^{60}$

In short, the revamped Council does not immediately present a sensational change from the form and functions of the body operating before the constitutional changes and the new federal law. ${ }^{61}$ Yet, the Kremlin retains flexibility in changing this. As Aleksandr Pozhalov has argued, it remains possible to amend these rules in order to adapt the Council to a particular task-and without needing to amend the constitution. ${ }^{62}$ In addition, personnel changes could also significantly affect the political importance of the body.

The State Council has been a perennial source of intrigue and disappointment during the constitutional reform process. Initially discussed as a way for Putin to deal with the '2024 problem', this view lost favor with the passing of the Tereshkova amendment. But interest increased again with the preparation and legislative introduction of draft legislation relating to the body. And yet, the lack of amendments during second reading in the Duma put to bed suspicions that the Council might have a clearer, weightier role in the near future. However, the fact that attention keeps returning to the Council, even after expectations were not met, says something important in itself-that

59 Although reporting on the State Council referred to eight additional regional heads (see Vinokurov and Rozhkova, "Gosudarevo "Oko"'), the Kremlin website originally listed nine, with the governor of Arkhangelsk Oblast', Aleksandr Tsybul'skii, appearing to be the additional member: http://www.kremlin.ru/structure/state-council/presidium. Given that these additional governors are appointed on a rotational basis to represent different federal districts, it could be that Tsybul'skii's appointment reflects the fact that a decision to create an Arctic district has already been made. On the discussion around creating such a district, see Kira Diuriagina and Elena Rozhkova, "Federal'nyi okrug Arkticheskii", Kommersant, 6 February 2020, https://www.kommersant.ru/doc/4244333.

6o Vinokurov and Rozhkova, "Gosudarevo "Oko"”.

61 See Fabian Burkhardt, "Institutionalizing personalism: The Russian presidency after constitutional changes", Russian Politics 6, no. 1 (2021): 50-70.

62 Makutina, "Organ soveshchatel'noi ...". The text in "Putin's constitution" relating to the State Council is only 38 words long (Article $83, \mathrm{e}(5)$ ) and includes few concrete details. 
the institution remains an important source of ambiguity and possible future development.

This ambiguity - the blurring of existing formal institutional differencesis a broader feature of the 'Putin constitution'. Article 10 of the 1993 Russian constitution declares a separation-of-powers system-one in which different branches of power have different responsibilities and can (at least in theory) check each other. Although this was never fully realized in practice, the notion of the 'unified system of public power'-elaborated for the first time in the State Council implementation bill-formalizes the chasm between the language of the constitution and politics in practice. In his 15 January 2020 Address, President Putin argued that his constitutional reforms would 'make interaction between the representative and executive branches of power more effective and meaningful. ${ }^{63}$ But, in reality, the 'unified system of public power' usurps what one Russian academic called the 'outdated' notion of the constitutional distinction of three branches of government. ${ }^{64}$

The 'unified system of public power' also undermines the formal autonomy of local self-government, even though Article 12 remains unchanged in stating that this layer of governance remains separate from the state. ${ }^{65}$ Steps in this direction - of practical limits on the independence of local self-governmentwere taken long before 2020, however. Only seven mayors of regional capitals remain elected by popular vote, all of them far away from Moscow: in Abakan, Anadyr, Khabarovsk, Novosibirsk, Tomsk, Ulan-Ude, and Yakutsk. ${ }^{66}$ And this small minority faces distinct pressures. For example, Tomsk mayor-Ivan Kliain, elected for a second term in 2018 - was arrested on far-fetched charges in November $2020 .{ }^{67}$ And a second criminal case was initiated against him at the end of December 2020.68 The lesson for other elected mayors is clear, with the Sword of Damocles hanging above their heads: although elected, their

63 Vladimir Putin, "Poslanie Prezidenta Federal'nomu Sobraniiu”, Kremlin, 15 January 2020, http://kremlin.ru/events/president/news/62582.

64 Garegin Mitin, "Organ novoi vetvi vlasti", Vedomosti, 20 November 2020, https://www .vedomosti.ru/opinion/articles/2020/11/19/847664-organ-novoi.

65 See William Pomeranz, "Putin's 2020 constitutional amendments: What Changed? What remained the same?", Russian Politics 6, no. 1 (2021): 6-26.

66 Il'ia Smirnov, Mariia Ignatova, Anastasiia Reutova, Iuliia Sasevich, and Andrei Prakh, "Deputaty merov ne otdaiut", Kommersant, 4 December 2020, https://www.kommersant .ru/doc/4596304.

67 "Mera Tomska zaderzhali po delu o prevyshenii polnomochii", Kommersant, 13 November 2020, https://www.kommersant.ru/doc/4567875.

68 "SK vozbudil vtoroe delo v otnoshenii otstranennogo mera Tomska Kliaina", $R B K$, 23 December 2020, https://www.rbc.ru/rbcfreenews/5fe31f659a79477067aab361. 
principal is not the people but senior state officials-their superiors in the 'unified system of public power'.

\section{$4 \quad$ Broader Political Developments}

Although this article has focused on the implementation of constitutional changes, it is useful to remember that the constitutional reform project itself is part of the implementation of a broader political transformation effort. ${ }^{69}$ One key feature of this broader project relates to elite management-a clear concern of the Kremlin in 'late Putinism'. As an indicator of this concern, both Vladimir Putin and Andrei Klishas admitted that a basic rationale for the Tereshkova amendment was to reduce the elite's fixation on the subject of the president's successor. ${ }^{70}$ This concern for elite management also informed other important elements of constitutional reform-such as increasing the dependence of Constitutional Court judges on the presidency, and citizenship and residency requirements for senior officials-as well as concurrent political developments not directly linked to constitutional change.

\subsection{Reshuffling of Cadres and Elite Repression}

On the same day that Vladimir Putin announced his constitutional reform project, the sitting prime minister, Dmitrii Medvedev, formally resigned from his post. ${ }^{71}$ The new cabinet, led by the former Federal Tax Service head, Mikhail Mishustin, was tasked with delivering on the 'National Projects' (an investment program led by the state, aimed at spurring social development and economic growth). November 2020 saw a reshuffle of Mishustin's cabinet, with new constitutional rules regarding the Duma's role in ministerial appointments used

69 Ben Noble and Nikolai Petrov, "President for Life? Behind the Facade, Putin's Power Is Weaker Than You Might Think", Newsweek, 19 March 2020, https://www.newsweek.com/ putin-president-life-weaker-1493314.

70 Vladislav Gordeev, "Kreml' zaiavil o postoiannoi smeniaemosti vlasti v Rossii", $R B K$, 22 June 2020, https://www.rbc.ru/politics/22/o6/2020/5efo6d299a79478884afb6c7. Evgeniia Kuznetsova, "Andrei Klishas-RBK: "Politiki dolzhny perestat' dumat' o transfere"”, $R B K, 22$ June 2020, https://www.rbc.ru/interview/politics/22/o6/202o/5eeb87f59a7 94754 b917b24f.

$71 \quad$ Mike Eckel and Todd Prince, "Putin Speaks, Medvedev Resigns, And Russia's Political World Turns Upside Down", RFE/RL, 15 January 2020, https://www.rferl.org/a/putin -speaks-medvedev-resigns-and-russia-s-political-world-turns-upside-down/3037947 9.html. 
for the first time (as discussed above). With Putin staying put, the Kremlin pointed to such cases as a sign of the 'rotation of power' in the country. ${ }^{72}$

These top-level changes might have attracted most media attention, but personnel changes at slightly lower levels demonstrate more turbulence in the federal-level shake-up of cadres in 2020. Take the judiciary and siloviki bodies. Two out of seven deputy chairs of the Supreme Court were replaced. ${ }^{73}$ January saw the replacement of Iuri Chaika as Prosecutor General by Igor' Krasnovformerly deputy head of the Investigative Committee. ${ }^{74}$ And all three major investigation chiefs in the country-in the Federal Security Service (FSB), the Ministry of Internal Affairs (MVD) and the Investigative Committee-were replaced. ${ }^{75}$ The appointment of Krasnov points, moreover, to an important feature of personnel reshuffling, with many individuals appointed from outside existing organizational corporations. The logic appears to be to interweave multiple power pyramids, introducing functional checks and balance-and preventing any one corporation dominating another. ${ }^{76}$

Repression has also been used as an elite management tool. Political repression against both federal and regional elites began on a mass scale in 2014. Regarding senior regional elites - a pool of around goo people-roughly $2-2.5$ percent of these individuals have been arrested each year. ${ }^{77}$ Following a slight pandemic-related dip, this level has continued, but, perhaps, with increased harshness. Key cases include those relating to former Khabarovsk Krai governor, Sergei Furgal; ${ }^{78}$ former Tomsk mayor, Ivan Kliain; ${ }^{79}$ former deputy head of the Ministry of Energy, Anatolii Tikhonov; former senior manager of 'Inter RAO'

72 Gordeev, “Kreml' zaiavil ...”.

73 Artem Filipenok, "Dva zamestitelia glavy Verkhovnogo suda reshili uiti v otstavku", $R B K$ 16 July 2020, https://www.rbc.ru/politics/16/o7/202o/5fioa88oga7947f93911a17d.

74 Noble and Petrov, "President for Life?".

75 Mikhail Iuzhkov, "SMI uznali ob otstavke nachal'nika sledstvennogo upravleniia FSB", $R B K, 5$ August 2020, https://www.rbc.ru/society/05/o8/2020/5f2ao2c59a79470161556b92. Georgii Tadtaev, "Putin otpravil v otstavku nachal'nika sledstvennogo departamenta MVD”, $R B K$, 9 April 2020, https://www.rbc.ru/society/o9/o4/2020/5e8f5dcega79475042738055. Nikolai Sergeev, "Voenno-sledstvennaia otstavka", Kommersant, 22 April 2020, https:// www.kommersant.ru/doc/4328553.

76 Henry Hale, Patronal Politics: Eurasian Regime Dynamics in Comparative Perspective. (New York: Cambridge University Press, 2015).

77 Nikolay Petrov, "Spiral' repressivnosti: vnutrenniaia dinamika, problemy vkhoda i vykhoda", Vestnik obshchestvennogo mneniia 1-2(128): 15-28. https://www.levada.ru/cp/wp -content/uploads/2019/o7/Book-1.pdf.

78 Yekaterina Khasina and Robert Coalson, “United Russia's Revenge? Far Eastern Governor's Arrest Raises Suspicions", $R F E / R L$, 9 July 2020, https://www.rferl.org/a/united-russia-s -revenge-far-eastern-governor-s-arrest-raises-suspicions/30716649.html. 
(an energy holding company), Karina Tsurkan; ${ }^{80}$ former Audit Chamber auditor, Minister of Construction, Housing and Communal Services, and Governor of Ivanovo Oblast', Mikhail Men'; ${ }^{11}$ and advisor to the head of Roscosmos, Dmitrii Rogozin, Ivan Safronov. ${ }^{82}$

In certain cases, there is a link between the pursuit by law enforcement of individuals and later formal political reshuffling. For example, Tikhonov was arrested in September, followed by the replacement of his superior, Aleksandr Novak, by Nikolai Shulginov as Minister of Energy in November. And the head of the Russian Venture Company (RVC), Aleksandr Povalko, was arrested in June before RVC was taken over by the Russian Direct Investment Fund later in the year. ${ }^{83}$ This sequence suggests central control of certain elite repression cases, although other cases likely reflect non-centralized, intra-elite, interfactional conflict.

\subsection{Quasi-Governments}

There have been a number of moves to fragment and restructure the executive. Contrary to the basic model of a Government (Cabinet of Ministers) responsible for governance and policy-making, headed by the prime minister and subordinate to the president, a number of what we might think of as quasi-governments have been formed. These include what could be called a 'presidential government' in the form of the Security Council; a 'foreign policy government' in the form of the Commission on Questions of International Development Assistance, headed by Dmitrii Kozak; ${ }^{44}$ a 'domestic development government' in the form of a strengthened VEB.RF—a state development

8o "Former Russian Energy Executive Given 15 Years On "Absurd" Spying Charge", RFE/RL, 29 December 2020, https://www.rferl.org/a/former-russian-energy-executive-spying -karina-tsurkan/31024463.html.

81 Dar'ia Napeeva, Vladimir Dergachev, and Anastasiia Golubeva, "Zaderzhan auditor Schetnoi palaty Mikhail Men'. Ego obviniaiut v khishchenii $700 \mathrm{mln}$ rublei", BBC Russkaia sluzhba, 18 November 2020, https://www.bbc.com/russian/news-54987364.

82 "Russian space official Safronov charged in treason probe", $B B C, 7$ July 2020, https://www .bbc.co.uk/news/world-europe-53319545.

83 Anastasiia Skrynnikova, Petr Kanaev, Dmitrii Serkov, Margarita Alekhina, and Evgeniia Kuznetsova, "V Moskve zaderzhali glavu Rossiiskoi venchurnoi kompanii", RBK, 4 June 202O, https://www.rbc.ru/technology_and_media/o4/o6/2020/5ed8ficd9a79479b odd5caa3. Petr Kanaev, Irina Parfent'eva, Anna Balashova, Anton Feinberg,and Timofei Dziadko, "Pravitel'stvo zapustit reformu institutov razvitiia", $R B K, 23$ November 2020, https://www.rbc.ru/business/23/11/2020/5fb8ce659a79471e74bd2245.

84 "Kozak vozglavil komissiiu po voprosam sodeistviia mezhdunarodnomu razvitiiu", TAss, 7 December 2020, https://tass.ru/politika/10194059. 
corporation-headed by Igor' Shuvalov, and having absorbed a number of existing development bodies; and a 'federal coordination government' in the form of the State Council. The apt metaphor for Russian political power, therefore, is not so much a two-headed eagle but a Hydra, with none of its heads dominating and posing a risk to the leader.

This creation of quasi-governments fits with the logic regarding the State Council—of blurring the existing formal boundaries between branches of power and distinct political institutions. For one thing, this institutional innovation - the creation of multiple government 'substitutes'85 —introduces even greater opacity regarding lines of accountability, including for Russian citizens to understand and use. But it also introduces more flexibility into the system: the structure and activities of most of these bodies are not described in detail in the constitution, even after the 2020 reforms, meaning that they are easily malleable in response to shifting conditions and needs (of Putin, most clearly) in the future.

\section{5}

\section{Conclusion}

At the time of writing, the implementation process is far from over. But it is still possible to reach a number of conclusions regarding this process. Implementing the 2020 constitutional changes was not simply the mundane work of legal bureaucrats - of the humdrum functioning of a bureaucraticauthoritarian regime. Far from merely being an automatic process—of lifting language from the revised constitution and updating legislation and other normative acts - the implementation process has exhibited creativity, messiness, conflict, complexity, and improvisation. But it also shows the difference between the rhetoric and the reality of the 'Putin constitution'.

In his 15 January 2020 Address to the Federal Assembly, President Vladimir Putin noted that the proposed constitutional reforms entailed 'very serious changes in the political system' that would 'increase the role and significance of the country's parliament, the role and significance of the State Duma'. ${ }^{86}$ And yet, this promise often contrasted markedly with the reality of the reform process following the Address, including when implementing changes through

\footnotetext{
85 Nikolay Petrov, Maria Lipman, and Henry Hale, "Three dilemmas of hybrid regime governance: Russia from Putin to Putin", Post-Soviet Affairs 30, no. 1 (2014): 1-26. https://doi.org /10.1080/1060586X.2013.825140.

Putin, "Poslanie Prezidenta ...".
} 
legislation and in the activities of parliamentary bodies. For instance, the State Duma's Committee on State Construction and Legislation held neither a meeting nor a discussion when deciding whether to recommend to the lower chamber to adopt the bills 'On Government' and 'On the Constitutional Court' in first reading. A simple poll of committee members was conducted. ${ }^{87}$ And, regarding the upper chamber of the Federal Assembly—the Federation Council-it was only approached to sign off on the introduction of Russian peacekeepers into Nagorno-Karabakh in November 2020 after these members of the armed forces had been sent to the region. ${ }^{88}$

To be sure, both examples can be nuanced. The restrictions on Duma committee activities were justified with reference to the exigencies of the pandemic; and Putin's spokesperson-Dmitrii Peskov—argued that a 3o December 2015 decision by the Federation Council giving its consent to the use of Russian armed forces abroad meant that the chamber did not have to do so again. ${ }^{89}$ And yet, even Viacheslav Volodin criticized Duma committees for not providing sufficient opportunity for deputies to discuss initiatives. ${ }^{90}$ Even with the pandemic, more could have been done, it seems, to give Duma deputies an opportunity to discuss implementation bills (in committees, at least). And, regarding the Federation Council, Peskov's stance was somewhat undermined by Andrei Klishas - chairman of the Council's Committee on Constitutional Legislation and State Construction - who pointed to a different reason for why Putin did not seek the upper chamber's approval before sending peacekeepers. Klishas argued that, since two Russian military members had been killed (with the shooting down of a helicopter by Azerbaijan over Armenia), Russian law allowed the president to dispatch troops to solve 'operational issues' without

87 Mariia Makutina, “Oppozitsiia pretenzii ne imeet”, Kommersant, 8 October 2020, https:// www.kommersant.ru/doc/4521425.

88 Andrei Pozniakov, "Sovet Federatsii postfaktum soglasoval vvod rossiiskikh mirotvortsev v Nagornyi Karabakh", Euronews, 18 November 2020, https://ru.euronews.com/2020/11/18/ putin-federation-council-peacekeepers-sanction.

89 The 2015 decision was in relation to the use of Russian forces in Syria, but the resolution did not state this explicitly, which, Peskov argued, meant that the Council's consent could be extended to the use of Russian peacekeepers in Nagorno-Karabakh. See "Sovet Federatsii razreshil Putinu ispol'zovat' voiska v Karabakhe. Peskov govoril, chto soglasie ne nuzhno", ввс Russkaia sluzhba, 18 November 2020, https://www.bbc.com/russian/ news-54971482.

$90 \quad$ Kseniia Veretennikova, "Shest' minut na popravku", Kommersant, 8 December 2020, https://www.kommersant.ru/doc/46o4709. It should be noted that Volodin's criticism was based on the fact that details not sorted out in committee would spill over into plenary sessions, thereby eating into precious plenary time. 
the consent of the Council. ${ }^{91}$ The multiple arguments suggested post hoc rationalization, rather than a sincere, considered position.

To cap this all off, the very end of 2020 saw a flurry of law-making with worrying implications for civil society and oppositional political activity. ${ }^{92} \mathrm{~A}$ 'firework display of prohibitive initiatives', the nature of these proposals and the speed with which they were adopted saw a return to use of the phrase 'mad printer' for the State Duma. ${ }^{93}$ Although these initiatives reflected the Kremlin's desire to increase its control over the September 2021 Duma elections, rather than implementing the constitutional changes as such, the law-making frenzy epitomized the hollow promise of Putin's 15 January Address. A reform project pitched as rebalancing power - away from the president and to parliament and other bodies - proved in its substance and implementation to move power in precisely the opposite direction.

\section{Acknowledgments}

The authors would like to thank Fabian Burkhardt and Elizabeth Teague for providing insightful comments on an earlier draft of the paper.

Support from the Basic Research Program of the National Research University Higher School of Economics is gratefully acknowledged by Ben Noble.

91 "Sovet Federatsii razreshil ...".

92 Andrei Pertsev and Farida Rustamova, "V kontse 2020 goda Gosduma vernulas' v rezhim “beshenogo printera”. Chtoby maksimal'no uslozhnit' zhizn' oppozitsii na vyborakh v 2021-m", Meduza, 26 December 2020, https://meduza.io/feature/202o/12/26/v-kontse -2020-goda-gosduma-vernulas-v-rezhim-beshenogo-printera-chtoby-maksimalno -uslozhnit-zhizn-oppozitsii-na-vyborah-v-2021-m.

93 Mariia Makutina, "Sprintery Gosudarstvennoi Dumy", Kommersant, 31 December 2020, https://www.kommersant.ru/doc/4637589. 